\title{
Revitalization of Coal Brownfields in Solving Environmental Problems and Structural Development of Kuzbass Economy
}

\author{
Vitaly Zhironkin ${ }^{1, *}$, and Juraj Janocko ${ }^{2}$ \\ ${ }^{1}$ National Research Tomsk Polytechnic University, 634050, 30 Lenina st., Tomsk, Russia \\ ${ }^{2}$ Technical University of Kosice, Faculty of Mining, Ecology, Process Control and Geotechnologies, \\ 042009 Letná, Kosice, Slovak Republic
}

\begin{abstract}
The life cycle of mines lasts from several years to several decades. The closure of the mine occurs when its recourses are completely extracted, or mining is no longer profitable within its leasehold. Most regulatory authorities all around the world require the plan of mines and open-pits closure even before the mining begins, as it must be determined that the site would not pose a threat to the environment or society in future. Depending on the location, the site of mine or open-pit may be used in alternative way after closure or restored to the pre-operational condition. Local authorities increasingly require financial assurance that the funds needed to close mining enterprises will also be available in emergency situations. Special attention is paid to the environmental insurance intended to limit liability related to pollution elimination after mining activities at abandoned fields are over. In close connection with environmental insurance is post-mining - the development of alternative use of mining sites after the closure of mines and open-pits.
\end{abstract}

\section{Introduction}

In the Russian economy, the de-industrial trend actively manifested in the 1990s led to the mass closure of mines, machinery plants and agricultural enterprises. As a result, entire areas have remained abandoned, economically depressed and difficult to access for infrastructure for more than twenty years.

Kuzbass (industrial region of the Western Siberia) - the largest coal basin in the Russian Federation - has more than 50 mines having been closed since the 1990s. The territories of many cities of the Kemerovo region (Kiselevsk, Prokopievsk, AnzheroSudzhensk) consist in large part of abandoned mine fields, and their social-and-economic situation is permanently deteriorating [1]. In this regard, the problems of revitalizing the Brownfields in Kuzbass being solved by increasing open-pit coal mining is in force up to now.

\footnotetext{
* Corresponding author: v.zhironkin@inbox.ru
} 


\section{Materials and Methods}

Different approaches to the analysis and evaluation of the abandoned mine or quarry fields, as well as to their definition, are determined by uneven state of the economy of various countries. For example, countries with high population density and competitive economy faced an urgent need to solve the problems with abandoned mine or quarry fields. In these countries the term "Brownfield" is understood as all abandoned areas, regardless their ecological condition: subsoil development sites, factory territories, agricultural land. These are the countries of the European Union, such as Great Britain, France, Germany, Austria, Belgium and Netherlands. On the contrary, low-density and highly competitive countries are focused on addressing environmental burdens or potential risks to human health, usually in urban areas. These countries view brownfields as abandoned territory only in the areas left by humans or contaminated with toxic substances. In the European Union such examples will be Denmark, Finland and Sweden [2-6].

Canada and the United States may be seen as countries having connected abandoned mining sites with environmental insurance.

In Russia brownfields represent deprivation epicenters of old industrial or agricultural territories with total depopulation (abandoned villages) or with structural degradation (mono-towns with closed plants and mines). Therefore, the issue of brownfields and their methodology is extremely relevant for Russia [6].

The etymology of the term "brownfield" is related to the color of land plots variously suitable for cultivation. While "greenfield" is an area or place with prosperous industry, i.e. a place which attracts investors in the construction of new enterprises, commercial and residential real estate, infrastructure then "blackfield" is a place abandoned by people affected by natural disasters, technological accidents, or influenced by deep economic depression (investors view investments within it as "toxic") [7].

So the brownfield is a territory which agricultural or industrial complex is almost destroyed, mainly for productive (depletion of mineral deposits or rural lands) or economic reasons (crisis of the national economy, fall of industry demand and prices, deep negative structural shift). The remains of production complex and infrastructure, settlements that could be brought back to life under certain circumstances, had been preserved [8]. Brownfields may have other economic potential, such as being used as tourism sites or national cultural heritage.

The problem of brownfields and their revitalization in the process of structural changes of national economy has become relevant for developed countries since 1960s. A common strategic vision for countries where mining was once highly developed is revitalization transforming brownfields into socially, economically and environmentally sound areas through coordinated efforts by all levels of government, private investors and local people (Fig 1) [9].

In Kuzbass, brownfields were formed in the 1990 s as a result of the decline in coal production and the closure of mines in the main coal clusters of the region:

- Northern Kuzbass cluster (Anzhero-Sudzhensk, Berezovsky, Kemerovo),

- Central Kuzbass cluster (Leninsk-Kuznetsky, Belovo, Prokopievsk, Kiselevsk),

- Southern Kuzbass cluster (Novokuznetsk, Mezhdurechensk, Myski, Osinniki), as well as in the ore cluster of Tashtagol destrict (ore mines in Kaz and Temir-Tau are closed). 


\begin{tabular}{|c|c|c|}
\hline GREENFIELD & BROWNFIELD & BLACKFIELD \\
\hline $\begin{array}{c}\text { Territory attracting } \\
\text { investors in the } \\
\text { construction of new } \\
\text { enterprises, housing, } \\
\text { infrastructure }\end{array}$ & $\begin{array}{c}\text { Remains of production complex } \\
\text { and infrastructure, settlements } \\
\text { that can be revived under certain } \\
\text { circumstances }\end{array}$ & $\begin{array}{c}\text { Territory abandoned by people } \\
\text { as a result of natural disasters or } \\
\text { technogenic accidents or deep } \\
\text { economic depression ("toxic" } \\
\text { for investors) }\end{array}$ \\
\hline GREENFIELD & BROWNFIELD \\
\hline \multicolumn{2}{|c|}{ REVITALIZATION } \\
\hline
\end{tabular}

Fig. 1. Revitalization in the circle "Greenfield, Brownfield and Blackfield".

The main peak in brownfield development was in 1993-2002, although many mines were officially closed by the late 2000s. On the Kuzbass map (Fig. 2), they are the clusters of closed mines (brown circles) in the North, Center and South of the region.

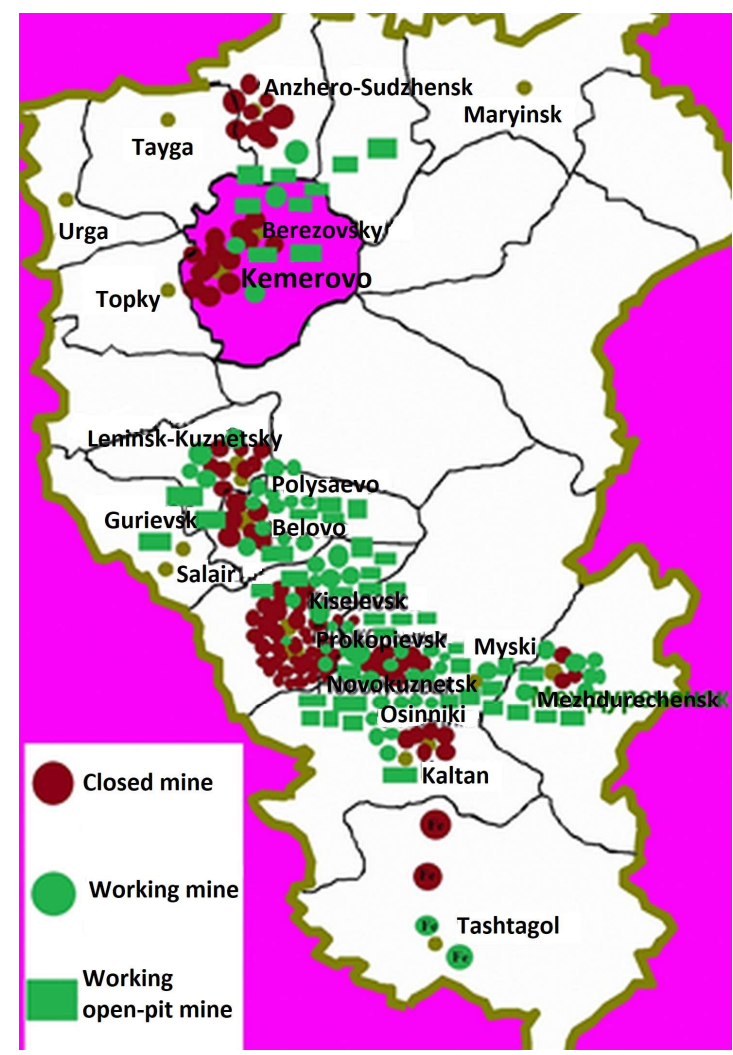

Fig. 2. The map of Brownfields and Greenfields in Kuzbass (drawn by author). 
From 2003 up to now, the process of revitalization of Kuzbass brownfields takes place as opening of new coal open-pit mines and reconstruction of some mines (Fig. 2, green squares and circles on the map). New greenfield of Kuzbass coal industry are presented by working mineral extracting enterprises [10].

Most of the closed mines formed brownfields in the North of Kuzbass (22 closed coal enterprises versus 13 currently operating ones), while in the Central Kuzbass 54 mines and their segments were closed, and now 52 enterprises are operating. Half of them are openpits, including working out old coal mine fields [11]. In the South of Kuzbass after the closure of 19 coal enterprises mining is carried out by 31 mine and open-pits [12]. Two iron mines (in the towns Kaz and Temir-Tau) were closed in Mountain Shoria, and two operate to nowadays (Tashtagol and Sheregesh) - Tab. 1.

Table 1. Sources of Brownfields and Greenfields in Kuzbass coal clusters

\begin{tabular}{|c|c|c|}
\hline Coal mining clusters of Kuzbass (Cities) & $\begin{array}{c}\text { Closed mines } \\
\text { and Sections }\end{array}$ & $\begin{array}{c}\text { Working mines } \\
\text { and open-pit mines }\end{array}$ \\
\hline $\begin{array}{c}\text { North Kuzbass (Anzhero-Suzhensk, } \\
\text { Kemerovo, Berezovsky) }\end{array}$ & 22 & 13 \\
\hline $\begin{array}{c}\text { Central Kuzbass (Leninsk-Kuznetsky, } \\
\text { Polysaevo, Belovo, Kiselevsk, } \\
\text { Prokopievsk) }\end{array}$ & 54 & 52 \\
\hline $\begin{array}{c}\text { South Kuzbass (Novokuznetsk, Myski, } \\
\text { Kaltan, Mezhdurechensk) and Mountain } \\
\text { Shoria iron ore cluster }\end{array}$ & 19 & 31 \\
\hline Total & 95 & 96 \\
\hline
\end{tabular}

Dynamics and prospects of coal production in Kuzbass are reflected on Fig 3. It shows us that the period of brownfields development occurred in 1993-2003, when a large part of the Kuzbass mines was closed or suspended.

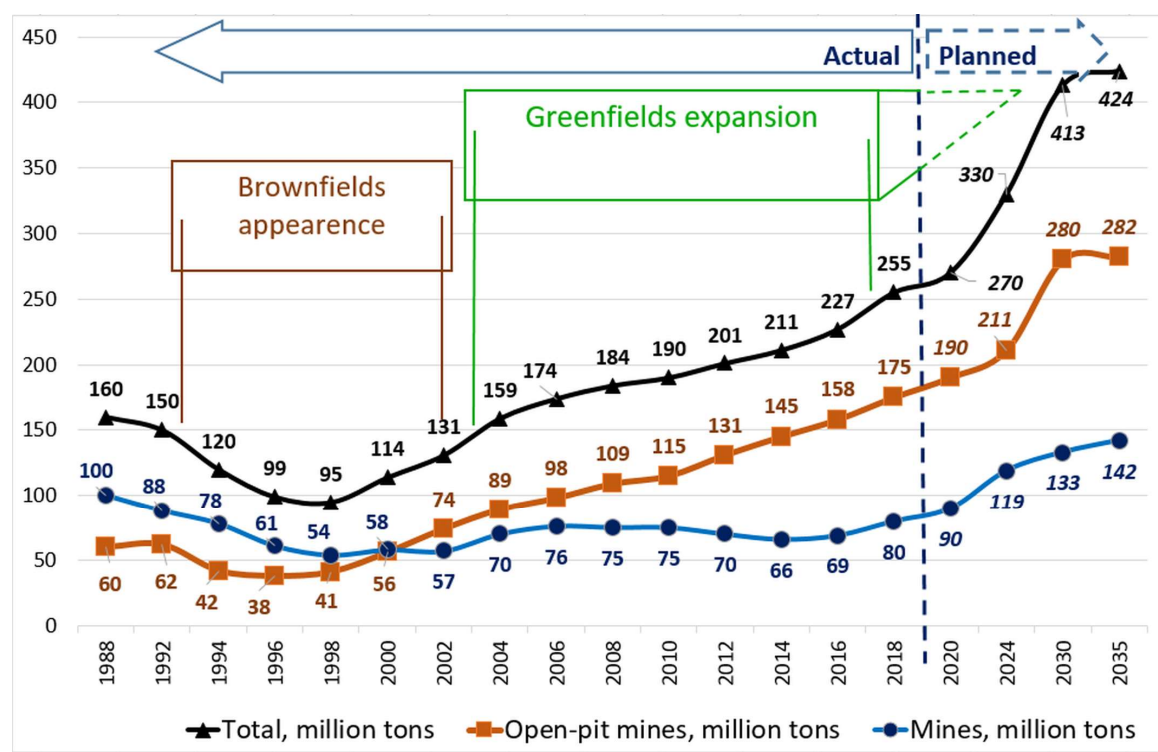

Fig. 3. Coal mining trends in Kuzbass (drawn by author). 
Later, from 2003, the growth of domestic and global demand for coal, as well as the cooperation between coal producers and the state-owned railway company (established by the State Council of 2002 in Mezhdurechensk) allowed to increase coal production to the level of the USSR (160 million tons annually) already in 2004, and reach 250 million tons by 2019. At the same time, the main increase in coal production is made by the coal open-pits - new and reconstructed ones [13].

Thus, the greenfields - the new coal enterprises - arise on the sites of brownfields in Kuzbass. As a result, in the coal towns of the Center and South of Kuzbass the economic activity is being revived, new housing is being built. By contrast, in Anzhero-Sudzhensk (the North Cluster), the economic depression is intensifying as many mines are still closed.

At the same time, the present greenfields of Kuzbass are very similar to brown fields, as they are clusters of coal enterprises, just working, not closed (Fig. 4 and 5).

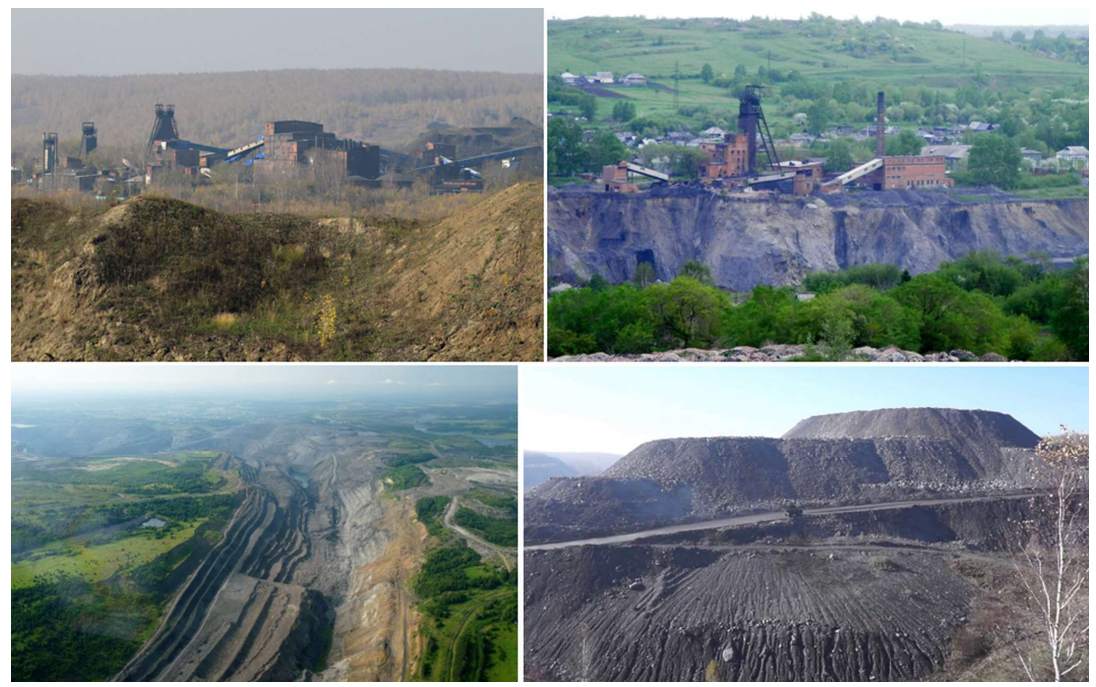

Fig. 4. View of brownfields in Kuzbass coal mining clusters.

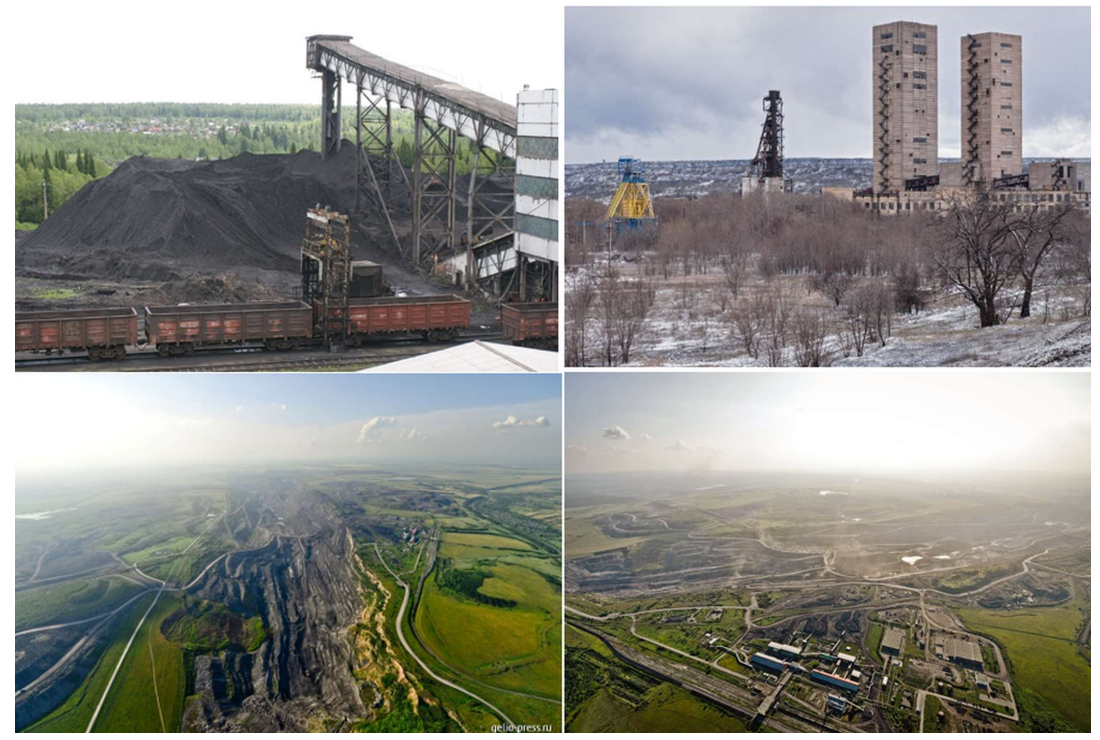

Fig 5. View of greenfields in Kuzbass coal mining clusters. 
The appearance of brownfields in 1990s had slightly reduced the burden on the environment, while their revitalization since the mid-2000s and the growth of greenfields, while bearing some social and economic benefits, does not improve, but deteriorates the regional environment - both in terms of land disruption and water and air pollution (Fig 6) [13, 14].

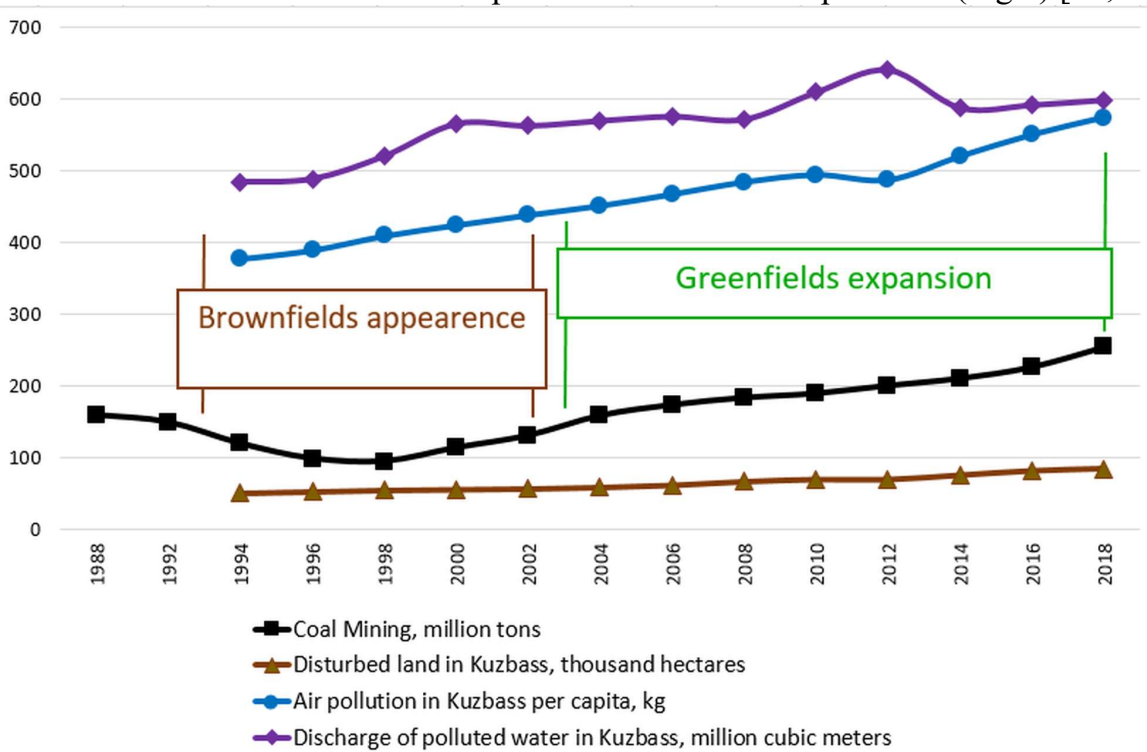

Fig. 6. Environmental damage compared to the volumes of coal mining in Kuzbass (drawn by author).

The diagram on Fig. 7 reflects the uncharacteristic process for modern greenfields depopulation process.

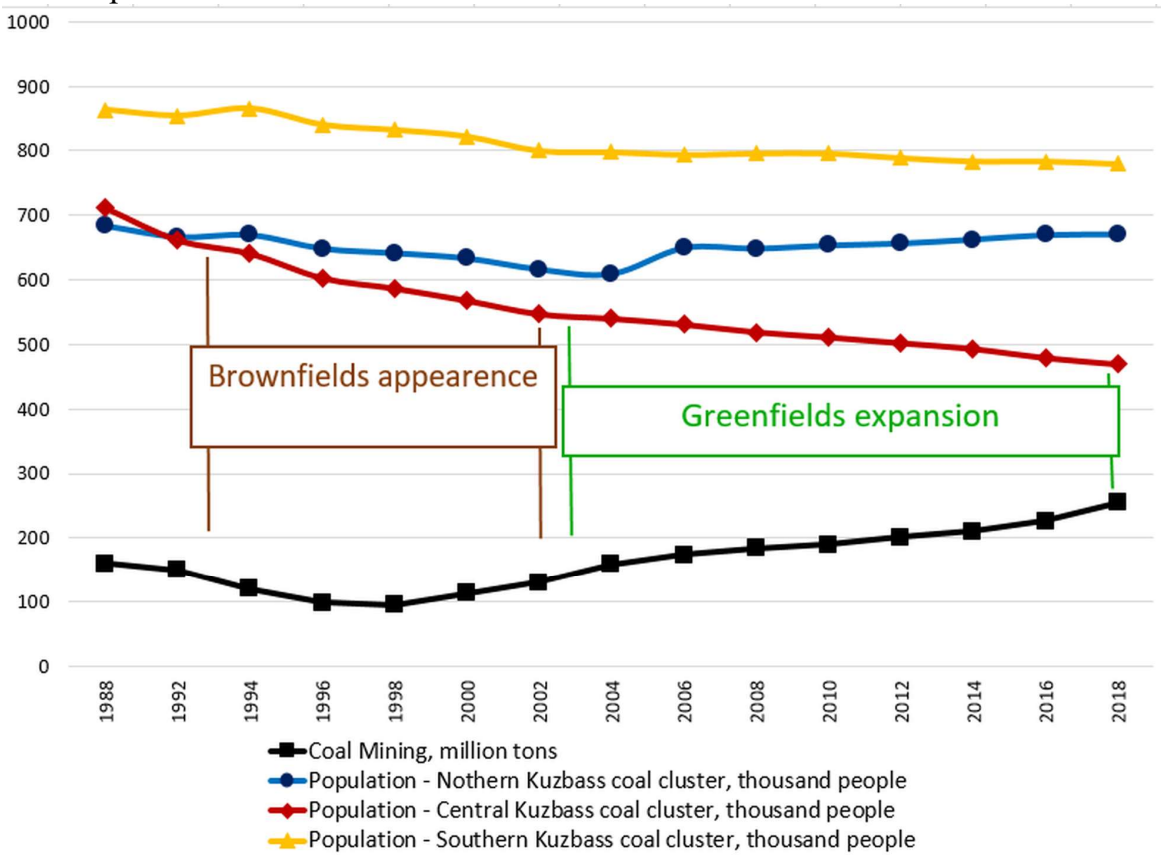

Fig. 7. Population growth/decrease compared to the volumes mined coal in Kuzbass (drawn by author). 
Over the last 25 years the population of Kuzbass has decreased by more than 250,000 people, especially in the South and in the Center of the region (the North is held by the inflow of people to Kemerovo). And these are the Center and South of the region where the most of new coal enterprises are created [15].

There has been no diversification and positive structural shifts in Kuzbass economy during brownfields revitalization, and many old problems remain. The transition from underground to predominantly open-pit coal mining, the prevalence of investment in the coal industry, negligence to the environmental problems and small business potential largely equate the Kuzbass greenfields with European brownfields.

There is a clear lack of a positive link between the growth of coal production and the development of entrepreneurial conditions for small businesses in the region. Since 2006, the number of individual entrepreneurs in Kuzbass has been steadily decreasing, and since 2010 - their sales turnover too [16] (Fig 8).

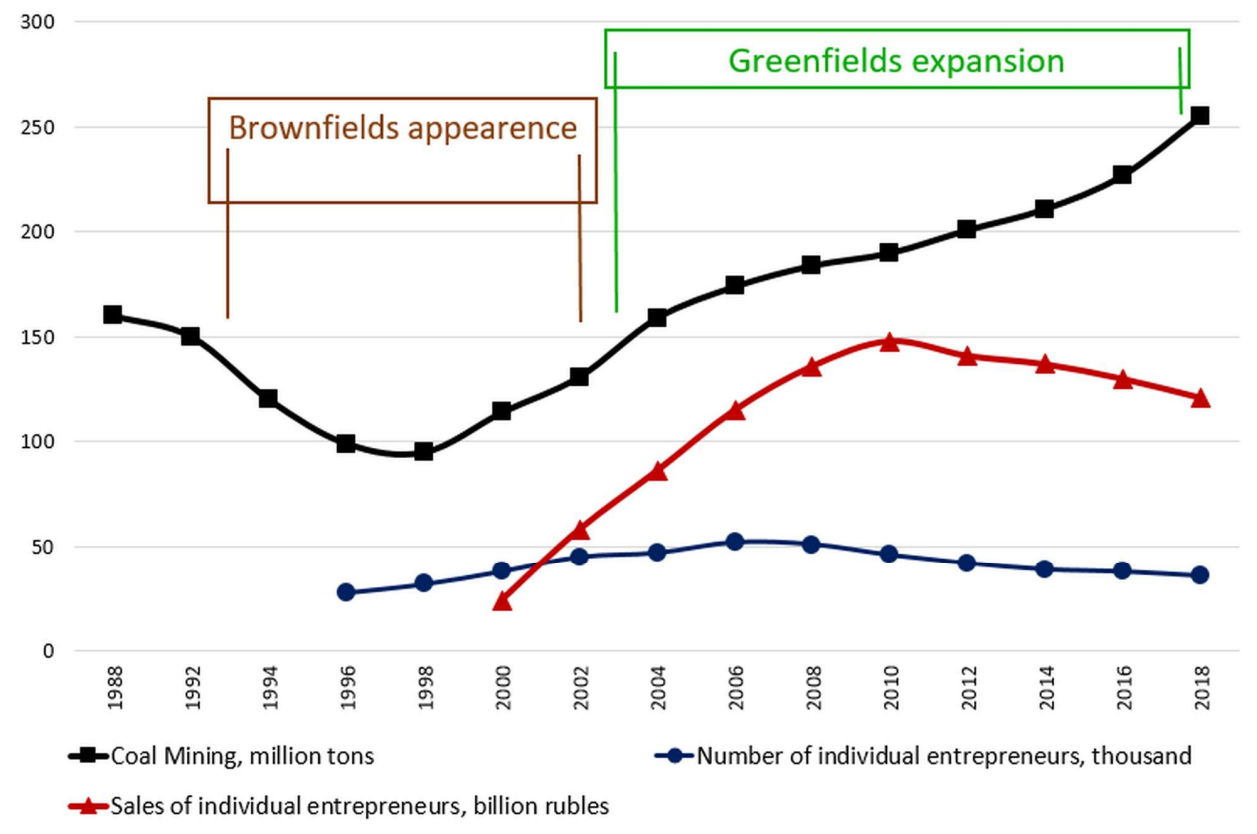

Fig. 8. Entrepreneurship dynamics compared to coal mining volumes in Kuzbass (drawn by author).

\section{Results and Discussion}

All mentioned above suggests that the existing mechanism for Kuzbass coal brownfields revitalizing is radically different from the European Union, as it does not improve the environment and does not allow the brownfield population to raise incomes outside the coal industry.

In this regard, it is appropriate to speak about the need to develop new mechanism of revitalization, the transition to greenfields of a new type.

It was clear that the creation of greenfields of the new type in Kuzbass, such as modern processing clusters of mechanical engineering, radio electronics, food industry, seems to be rather difficult in future, as it was not reflected in strategic documents (such as the Strategy for Social and Economic Development of Kemerovo Region until 2035). The machinery 
enterprises of former USSR, located in the towns Urga, Anzhero-Sudzhensk, Prokopievsk, Kemerovo today are also a kind of brownfield: they are closed, and technologies are irretrievably lost.

Another way of revitalization is implementation of new technologies for coal mining, for example, underground gasification of coal and methane extraction from coal seams did not take hold in Kuzbass.

The remaining promising way is the post-mining, that means the development of alternative activities in the brownfield territories.

The European Union countries are developing environmental insurance legislation as legal and the financial basis of post-mining. It allows the restoration of brownfield environment in future while mineral resources are being exploited today.

Environmental insurance makes it possible to place some of the revitalization activities of future investors on the acting mining companies [17, 18]:

A) liability insurance of mining companies for damage to land sites and their improper reclamation;

B) property insurance of residential areas and peasant farms in case of damage caused by accidents at mining enterprises;

C) insurance of costs of future investors in recovering brownfield's environment based on the "stop-loss" principle which sets the upper limit of their compensation;

D) personal insurance of life, health and property of mining enterprises employees.

Despite the variety of types of environmental insurance, it means the insurance of the liability of active investors to future ones who will convert brownfields and improve ecology.

Post-mining as a most promising way of brownfield revitalization means the development of alternative energy, ethnic and industrial tourism, and the re-establishment of agriculture after the restoration of disturbed lands. All this is successfully implemented in the Ruhr Basin in Germany, in Spanish Catalonia, where mines and open-pits were closed (Fig. 9 [19]).

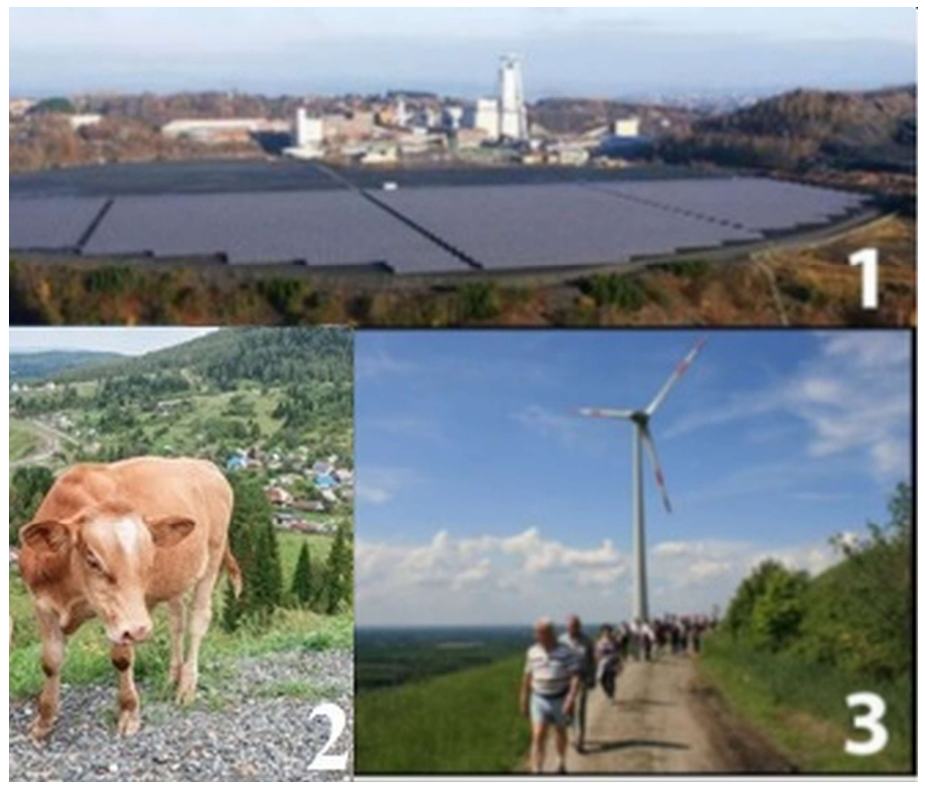

Fig. 9. Conversion of coal industry clusters and development of alternative types of employment of the population: 1) development of alternative power engineering (wind, solar, thermal); 2 reconstruction of agricultural industry; 3 ) development of ethno-graphic tourism based on old mines, open-pits. 


\section{Conclusion}

The main task assigned to the revitalization of brownfields is to integrate the restoration of production and economic activities on the depleted sites and old industrial areas at a new technological level. It also means reducing damage caused by mining to the environment.

By the example of Kuzbass, one can clearly see the negative results of the attempt to revitalize brownfields (abandoned mines closed in the 1990s as a result of the financial crisis in Russia) in the way of a transition from open to underground coal mining, with an increase in its volumes. These negative results include continuing environment deterioration, an increase in depopulation and a reduction in the attractiveness of the region for private investors (outside the coal industry).

A genuine solution of the brownfields problem in coal clusters of Kuzbass requires involving all participants such as business, authorities, the population, public organizations and trade unions in the process of revitalization. One of the main conditions for solving the issue of coal brownfields is the development of post-mining, as well as the establishment of an effective environmental insurance system. The latter will reduce the investment costs of future investors in restoring ecological balance and improving social infrastructure in the region.

\section{References}

1. N. N. Golofastova, V. G.Mikhailov, I. V. Seredyuk, Economics and Innovation Management, 1, 66-75 (2017) DOI: 10.26730/2587-5574-2017-1 -66-75

2. Environmental Protection Agency (EPA), Brownfields Assessment Grants FactSheet (Environmental Protection Agency, Washington, 2009)

3. Environmental Protection Agency (EPA), Potential Insurance Products for Brownfields (EPA, Washington, 1996)

4. U. Ferber, Brownfields Handbook, Lifelong Educational Project on Brownfields; Tech. Rep. Leonardo Da Vinci Pilot Project CZ /04/B/F/PP-168014 (Silezian University, Gliwice, 2006)

5. B. H. Fisher, Brownfields Redevelopment and Gentrification: A Socio-Economic Evaluation of the EPA Brownfields Pilot Program (Iowa State University, Ames, 2011)

6. J. Janocko, M. Cehlar, Z. Simkova, Economics and Innovation Management, 3(3), 32-45 (2017) DOI: 10.26730/2587-5574-2017-3-32-45

7. H. Pavolová, L. Domaracká, N. Mitterpachová, The Impact of Environmental Burden on the Reuse of Brownfields in Slovakia (Univerisities of Košice Publishing, Košice, 2009)

8. M. Cehlár, L. Mihok, Theoretical and Empirical Researches in Urban Management, 8:4, 60-72 (2013)

9. S. Zhironkin, S. Demchenko, G. Kayachev, M. Ryzhkova, O. Zhironkina, E3S Web Conf., 41, 04011 (2018)

10. O.O. Garshin, Z.A. Startseva, 2:5, 33-41 (2019) DOI: 10.26730/2618-7434-2019-2-3341

11. T. Gvozdkova, M. Tyulenev, S. Zhironkin, V. A. Trifonov, Yu. M. Osipov, IOP Conf. Ser.: Earth Environ. Sci., 50:1, 012010 (2017)

12. Mining Encyclopedia, URL: http://miningwiki.ru/wiki 
13. Coal Mining Department of the Kemerovo Region Administration. Section: Mined Coals, URL: http://www.ugolprom-kuzbass.ru/industry/indicators/mining/

14. T.V. Kiseleva, V.G. Mikhailov, Economics and Innovation Management, 4, 70-78 (2018). DOI:10.26730/2587-5574-2018-4-70-78

15. Ecology and Natural Resources Department of the Kemerovo Region Administration. The annual report, URL: https://ako.ru/upload/medialibrary/7ff/doklad_2017.pdf

16. Territorial branch of the Federal Service of State Statistics in the Kemerovo region. Section: Entrepreneurship, URL: https://kemerovostat.gks.ru/folder/38691

17. M. Cehlar, J. Janocko, Z. Simkova, T. Pavlik, M. Tyulenev, S. Zhironkin, M. Gasanov, Resources, 8:1, 21 (2019)

18. M. Cehlár, L. Domaracká, I. Šimko, M. Puzder, Mineral Resource Extraction and its Political Risks; Environmental Science, Policy and Management (ESPM Workshop, Tatranská Štrba, 2015)

19. J. Kretschmann, A. B. Efremenkov, A. A. Khoreshok, IOP Conf. Series: Earth and Environmental Science, 50, 012024 (2017) 